\title{
Effect of Cathode Microstructure on Electrochemical Properties of Sodium Nickel-Iron Chloride Batteries
}

\author{
Byeong-Min Ahn ${ }^{1,2}{ }^{\mathbb{D}}$, Cheol-Woo Ahn ${ }^{1, *}$, Byung-Dong Hahn ${ }^{1}$, Jong-Jin Choi ${ }^{1}$, Yang-Do Kim ${ }^{2}$, Sung-Ki Lim ${ }^{3}$ \\ and Joon-Hwan Choi ${ }^{1, *}$
}

1 Korea Institute of Materials Science (KIMS), Changwon 51508, Gyeongnam, Korea; vhehtkfkd123@kims.re.kr (B.-M.A.); cera72@kims.re.kr (B.-D.H.); finaljin@kims.re.kr (J.-J.C.)

2 Department of Materials Science and Engineering, Pusan National University, Busan 46241, Korea; yangdo@pusan.ac.kr

3 Department of Material Chemistry and Engineering, Konkuk University, Seoul 143-701, Korea; sklim@konkuk.ac.kr

* $\quad$ Correspondence: cheoruahn@kims.re.kr (C.-W.A.); jchoi@kims.re.kr (J.-H.C.); Tel.: +82-55-280-3406 (C.-W.A.)

check for updates

Citation: Ahn, B.-M.; Ahn, C.-W.; Hahn, B.-D.; Choi, J.-J.; Kim, Y.-D.; Lim, S.-K.; Choi, J.-H. Effect of

Cathode Microstructure on

Electrochemical Properties of Sodium Nickel-Iron Chloride Batteries. Materials 2021, 14, 5605. https:// doi.org/10.3390/ma14195605

Academic Editors: Guosheng Li, Vincent Sprenkle and Federico Bella

Received: 25 August 2021

Accepted: 24 September 2021

Published: 27 September 2021

Publisher's Note: MDPI stays neutral with regard to jurisdictional claims in published maps and institutional affiliations.

Copyright: (c) 2021 by the authors. Licensee MDPI, Basel, Switzerland. This article is an open access article distributed under the terms and conditions of the Creative Commons Attribution (CC BY) license (https:/ / creativecommons.org/licenses/by/ $4.0 /)$.

\begin{abstract}
Sodium metal chloride batteries have become a substantial focus area in the research on prospective alternatives for battery energy storage systems (BESSs) since they are more stable than lithium ion batteries. This study demonstrates the effects of the cathode microstructure on the electrochemical properties of sodium metal chloride cells. The cathode powder is manufactured in the form of granules composed of a metal active material and $\mathrm{NaCl}$, and the ionic conductivity is attained by filling the interiors of the granules with a second electrolyte $\left(\mathrm{NaAlCl}_{4}\right)$. Thus, the microstructure of the cathode powder had to be optimized to ensure that the second electrolyte effectively penetrated the cathode granules. The microstructure was modified by selecting the $\mathrm{NaCl}$ size and density of the cathode granules, and the resulting $\mathrm{Na} /(\mathrm{Ni}, \mathrm{Fe}) \mathrm{Cl}_{2}$ cell showed a high capacity of $224 \mathrm{mAh} \mathrm{g}^{-1}$ at the 100th cycle owing to microstructural improvements. These findings demonstrate that control of the cathode microstructure is essential when cathode powders are used to manufacture sodium metal chloride batteries.
\end{abstract}

Keywords: sodium nickel chloride; iron; battery; cell capacity; microstructure; low cost; durability; $\mathrm{NaCl}$ size; granule density; cycle retention

\section{Introduction}

Battery energy storage systems (BESSs) are an indispensable technology due to the global growth in electric energy consumption. Although various types of BESSs are available [1-4], most BESSs consist of lithium ion batteries (LIBs) because of their many advantages, such as high energy density and efficiency. However, in the BESS field, size enlargement of LIBs has proven difficult, and they also exhibit a safety issue. $\mathrm{Na} / \mathrm{NiCl}_{2}$ batteries are promising alternatives to other types of BESSs as they overcome these problems; that is, they are safer and easier to scale up than LIBs. Furthermore, $\mathrm{Na} / \mathrm{NiCl}_{2}$ batteries offer merits such as a high energy density and low cost. However, commercial $\mathrm{Na} / \mathrm{NiCl}_{2}$ cells have poor price competitiveness because of the large amount of Ni they contain and their high operation temperature. Because of these weaknesses, many experimental strategies for improving $\mathrm{Na} / \mathrm{NiCl}_{2}$ batteries have been attempted, such as replacing the $\mathrm{Ni}$ in the cathode with other metals [5-10], decreasing the operating temperature [11-14] and enhancing Ni-based cathodes [15-18]. However, the cathode microstructure, which is essential for in-depth cathode studies on topics such as the $\mathrm{NaCl}$ size effect or granule density, has not been researched in detail. Nonetheless, other studies have examined the influence of increased $\mathrm{NaCl}$ size after cycling under various conditions [12]. However, this result was related to the effects of cell degradation. Additionally, although the effect of $\mathrm{NaCl}$ size on $\mathrm{Na} / \mathrm{AlCl}_{3}$ batteries was briefly studied [6], its effect on $\mathrm{Na} / \mathrm{NiCl}_{2}$ and $\mathrm{Na} /(\mathrm{Ni}, \mathrm{Fe}) \mathrm{Cl}_{2}$ 
batteries remains unidentified. Moreover, the effects of the granule manufacturing process have been studied [19], but this study mainly analyzed the granule production conditions, whereas the microstructure was not examined in detail.

We previously studied microstructure control in $\mathrm{Na} /(\mathrm{Ni}, \mathrm{Fe}) \mathrm{Cl}_{2}$ batteries [17]. A method of control of the $\mathrm{Ni}$ and Fe particle sizes was used to improve the electrochemical properties of the cell with an increase in the connectivity between the Ni particles. Further, a $\mathrm{Na} /(\mathrm{Ni}, \mathrm{Fe}) \mathrm{Cl}_{2}$ battery with an optimized $\mathrm{Ni} / \mathrm{Fe}$ ratio was fabricated [18], which demonstrated the properly divided roles of the Fe and Ni particle. Specifically, the Fe particles mainly contributed to the charge-discharge process, and the Ni particles maintained electron paths with minimized electrochemical reaction, as shown in the schematics of Figure 1a. In addition, decreasing the Ni content $(\mathrm{Ni} / \mathrm{Fe}=1 / 1$, metal $/ \mathrm{NaCl}=1.5 / 1)$ lowered the cost, and the cells thus constructed were more durable than $\mathrm{Na} / \mathrm{NiCl}_{2}$ batteries. However, previous $\mathrm{Na} /(\mathrm{Ni}, \mathrm{Fe}) \mathrm{Cl}_{2}$ cells showed a problematic decline in capacity; owing to a lack of additional microstructure optimization except for $\mathrm{Ni}$ and Fe size control, the cell capacity after 50 cycles decreased below $200 \mathrm{mAh} \mathrm{g}^{-1}$ (per weight of $\mathrm{Ni}-\mathrm{Fe}$ particles). Thus, in this study, we first considered the density of the cathode granules, which is a fundamental aspect of the microstructure, before examining the effect of the $\mathrm{NaCl}$ size in the cathode materials. We divided the $\mathrm{NaCl}$ size into three ranges $(<38,38-150$ and 150-300 $\mu \mathrm{m}$ ) and the granule density into two levels (low density: $10 \mathrm{MPa}$, high density: $200 \mathrm{MPa}$ ). Additionally, we investigated the correlation between the microstructure and electrochemical properties by controlling the $\mathrm{NaCl}$ size and granule density to prevent the capacity of the $\mathrm{Na} / \mathrm{NiCl}_{2}$ cells from declining. Consequently, the $\mathrm{NaCl}$ size and granule density were optimized to improve the electrochemical properties of the modified $\mathrm{Na} /(\mathrm{Ni}, \mathrm{Fe}) \mathrm{Cl}_{2}$ battery.
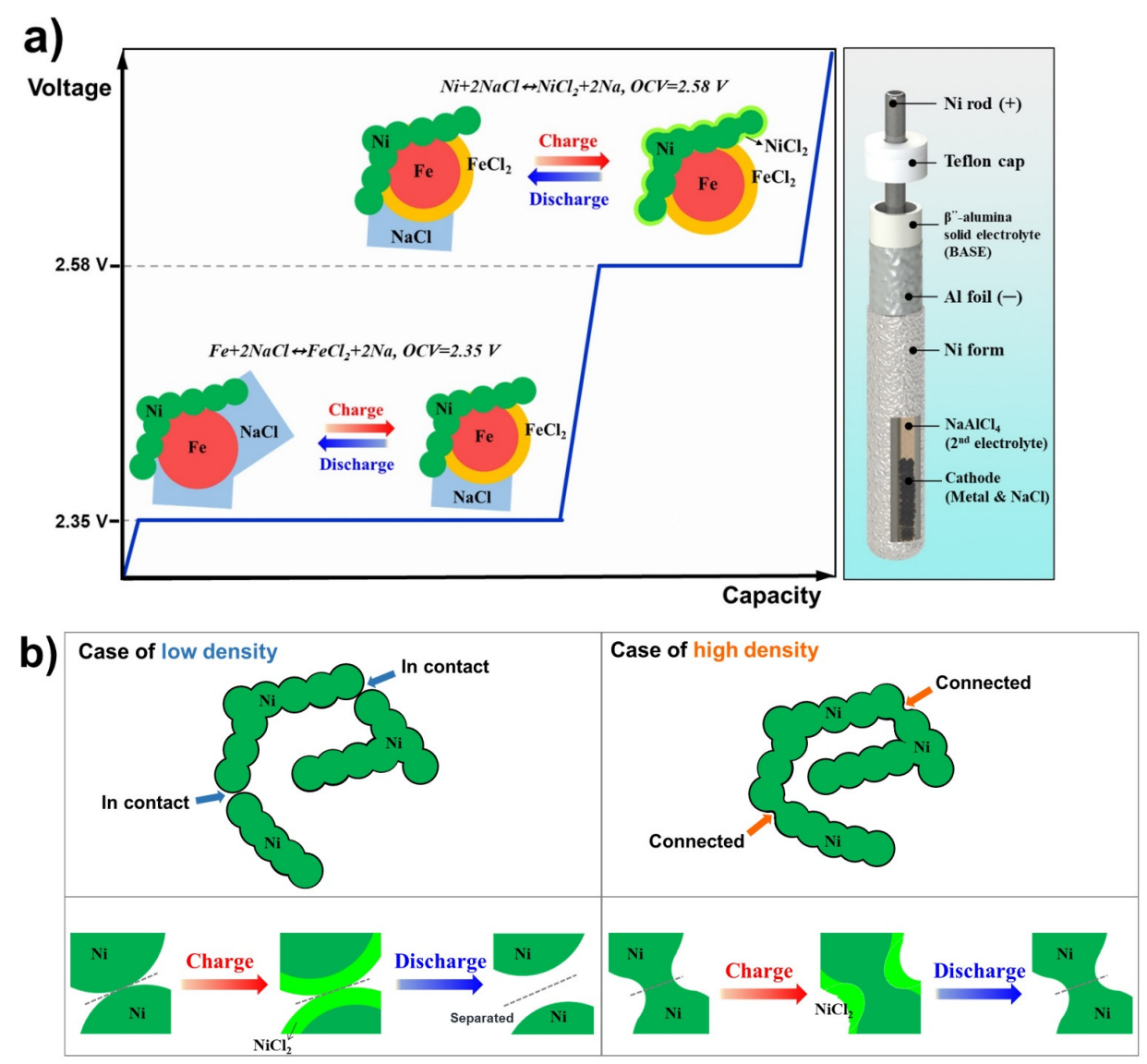

Figure 1. Schematic diagrams. (a) charge-discharge mechanism of $\mathrm{Na} /(\mathrm{Ni}, \mathrm{Fe}) \mathrm{Cl}_{2}$ cell and simple test cell structure; (b) difference in the Ni connection shape between low and high densities. 


\section{Experimental Section}

\subsection{Preparation of Cathode Granules}

$\mathrm{NaCl}(98 \%$, Sigma Aldrich, Burlington, MA, USA) was sieved and classified into three size grades: small $(<38 \mu \mathrm{m})$, medium $(38-150)$, and large $(150-300 \mu \mathrm{m})$. For the cathode of the $\mathrm{Ni}$ cell, three grades of $\mathrm{NaCl}$ powders were each separately mixed with raw Ni powder $(99.7 \%, 2.5 \mu \mathrm{m}$, Standard Grade, Vale) by ball milling without balls for $2 \mathrm{~h}$. The $\mathrm{Ni}-\mathrm{NaCl}$ mixtures were prepared with a Ni/NaCl ratio of 2/1. A 1:1 mixture of $\mathrm{Ni}$ and $\mathrm{Fe}(99.5 \%$, $6.5 \mu \mathrm{m}, \mathrm{BASF}$, Ludwigshafen, Germany) was mixed with a Turbula-type T2C shaker mixer (Willy A. Bachofen AG, Uster, Switzerland) for $2 \mathrm{~h}$ to reinforce the connection between the metal powders. The mixing process for the metal and $\mathrm{NaCl}$ in the $\mathrm{Ni}-\mathrm{Fe}$ cell was the same as that of the Ni cell. The cathode of the $\mathrm{Ni}-\mathrm{Fe}$ cell used a metal/ $\mathrm{NaCl}$ ratio of 1.5/1. The granule density was measured using Archimedes' method. Although this method is inaccurate because of the pores penetrating the granule surface, it can be used to simply compare the densities of the two processes. For comparison, the densities in this study were thus expressed as relative densities (\%). The granule density was divided into two conditions, low and high. Low-density granules were pressed at $10 \mathrm{MPa}$ and had a relative density within the range of $28-37 \%$. High density granules were pressed at $200 \mathrm{MPa}$ and had a density of $52-56 \%$. The pressed sheet was ground using a granulator, and the granule size was $300 \mu \mathrm{m}$ to $1 \mathrm{~mm}$.

\subsection{Synthesis Method and Additives of Second Electrolyte}

The $\mathrm{NaAlCl}_{4}$ (the 2nd electrolyte) was synthesized using $\mathrm{NaCl}$ and $\mathrm{AlCl}_{3}(99.985 \%$, Alfa Aesar, Ward Hill, MA, USA) powders at $300^{\circ} \mathrm{C}$ for $1 \mathrm{~h}$. For ideal crystallization, the synthesized liquid $\mathrm{NaAlCl}_{4}$ was cooled in a furnace. After the cooling step, solid $\mathrm{NaAlCl}_{4}$ was ground using a mortar with approximately $5 \mathrm{wt} . \%$ sulfur powders (reagent grade, -100-mesh, Sigma Aldrich, Burlington, MA, USA) to remove the oxide layers on the metal surface in the cathode [19].

\subsection{Configuration of a Simple Test Cell}

Figure 1 shows the schematic of a simple test cell. The $\beta$ "-alumina solid electrolyte (BASE; Ionotec, Berkeley, UK) was wrapped with $\mathrm{Al}$ foil and fixed using the Ni form. The Al foil played two roles: a place for storing the Na melt and a current collector on the anode side. The cathode current collector was made of a Ni rod, and the upper side of the cell was sealed with a Teflon cap to prevent contamination. The anode side of BASE tube was coated with carbon paste (Research Institute of Industrial Science and Technology (RIST), Pohang-si, Korea) to improve the wettability of Na melt to the BASE surface [20]. The BASE tube was heat-treated at $230^{\circ} \mathrm{C}$ for $30 \mathrm{~min}$ after carbon coating to remove a polymer and water contained in the carbon paste.

\subsection{Test Condition of Cells}

All test cells were set up at $300{ }^{\circ} \mathrm{C}$ in the electric furnace which was located inside the Ar-filled glove box. Moisture and oxygen concentration were maintained at less than $1.0 \mathrm{ppm}$. The Ni-only cells were cycled using VMP3 (Bio Logic SAS, Seyssinet-pariset, France) between $2.4 \mathrm{~V}$ and $2.8 \mathrm{~V}$, and the C-rate was set to C/2. The 1.5LNF-low cell was cycled between $2.2 \mathrm{~V}$ and $2.7 \mathrm{~V}$ and the $\mathrm{C}$-rate was set to $\mathrm{C} / 8$. The microstructure of cathode was observed using a scanning electron microscope (SEM, IT-300; JEOL CO., Tokyo, Japan). Slightly different conditions were applied to the 1.5SNF-high cell compared to the 1.5LNF-low cell, except the operation temperature and cut-off voltage $(2.2-2.7 \mathrm{~V})$. The C-rate was controlled with five steps. Initially, the first step was cycled at $34 \mathrm{~mA} \mathrm{~g}^{-1}$ to the 4 th cycle for stabilization. The second and third steps increased the current density double and triple, respectively, for 5 cycles at each step due to the examination the rate capability. Additionally, the fourth step was set up at a slow rate of $34 \mathrm{~mA} \mathrm{~g}^{-1}$ again to the 19th cycle. Lastly, for the verification of cycle retention, the cells were cycled at $67 \mathrm{~mA} \mathrm{~g}^{-1}$ to the 100th cycle. The characterization of the microstructure is the same as for other cells. 


\section{Results and Discussion}

\subsection{Electrochemical Effects of Granule Density and $\mathrm{NaCl}$ Size in the $\mathrm{Na} / \mathrm{NiCl}_{2}$ Cells}

We divided the granule into high-density and low-density according to the pressure, and performed an electrochemical test with three sizes of $\mathrm{NaCl}$ for each density. The microstructure of the low-density granules is shown schematically in Figure 1b, wherein agglomerates of Ni particles are simply in contact. During the initial cycle, this contact provided sufficient interparticle connectivity. However, as charge-discharge proceeded, a $\mathrm{NiCl}_{2}$ layer was repeatedly generated and destroyed on the Ni surface; eventually, $\mathrm{Ni}$ particles that were previously only in contact became separated. Since these separated $\mathrm{Ni}$ particles could not participate in the electrochemical reaction, the capacity decreased as the cycle proceeded. Conversely, in high-density granules formed under a higher pressure, the Ni agglomerates were well connected between particles. This strong connectivity was maintained even after charge-discharge cycling due to the $\mathrm{NiCl}_{2}$ layer that was created only on the Ni surface. This Ni connectivity was a key factor in the cycle retention of the high-density cells.

The difference in granule density was confirmed using the SEM images in Figure 2. Figure 2a,c shows that in the low-density granules, Ni particles were simply in contact (blue arrows). By contrast, the strong connections frequently existed in the high-density granule microstructure (red arrows). In fact, the microstructure of each cell was similar to the corresponding schematic diagram in Figure 1b. However, the microstructure of the high-density granules also showed a disadvantage when observed at a lower magnification. For excellent battery operation, the cathode must have sufficient porosity for the liquid electrolyte to fully penetrate [21]. For 2SN-low in Figure 2e,i and 2SN-high in Figure 2f,j, both of which used small $\mathrm{NaCl}$, the microstructure of the high-density granule seemed slightly dense, which means that the $2 \mathrm{SN}$-low granules that have a wider contact area with the second electrolyte were favorable for a high initial capacity. The 2LN-low and 2LN-high cells showed similar tendencies. However, when the $\mathrm{NaCl}$ surface was large, the $\mathrm{Ni}$ layer was compressed on this surface owing to the high pressure. This compressed Ni layer may be another factor that interrupts the contact between the second electrolyte and $\mathrm{NaCl}$, in addition to granule porosity.

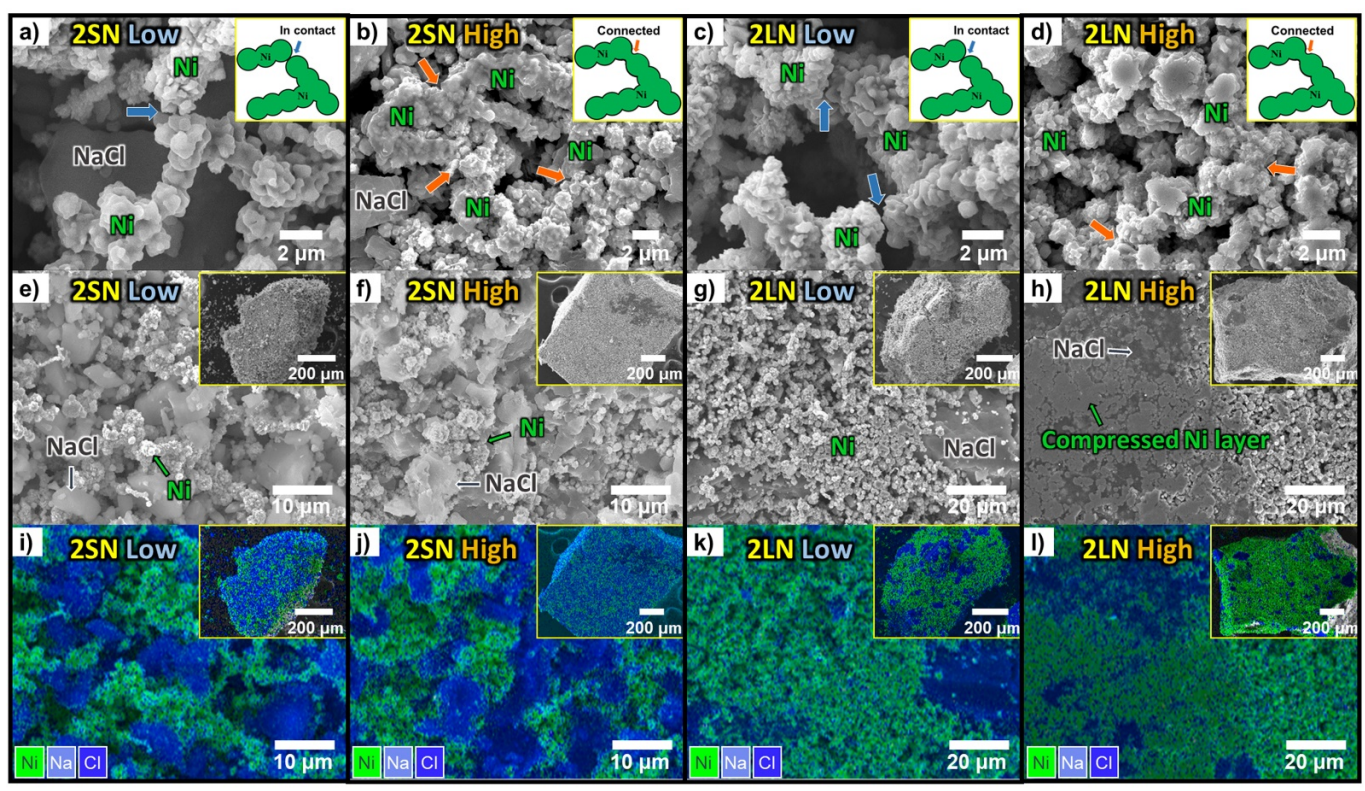

Figure 2. SEM images of cathode granule in 2SN and 2LN with different granule densities. (a-d) shape of Ni connection in each condition; $(\mathbf{e}-\mathbf{h})$ granule surface and microstructure of each cell; (i-1) EDS mapping data of each cell. (green: $\mathrm{Ni}$, blue: $\mathrm{NaCl}$ ). 
Figure 3a shows the voltage profiles of all Ni cells at the second cycle, and as expected, the low-density cells indicated higher initial capacities than the high-density cells. The initial capacity of the low-density cells ranged from 165 to $184 \mathrm{mAh} \mathrm{g}^{-1}$. Thus, compared with the high-density cells (120-157 $\left.\mathrm{mAh} \mathrm{g}^{-1}\right)$, the low-density granules were more favorable to a high initial capacity. As mentioned above, the high porosity of low-density granules facilitates the penetration of the second electrolyte into the granules; hence, the activation volume of low-density granules is higher than that of high-density granules. The initial capacity differences of $2 \mathrm{LN}, 2 \mathrm{MN}$ and $2 \mathrm{SN}$ cells, which have different densities, were 64,38 and $8 \mathrm{mAh} \mathrm{g}^{-1}$, respectively. Particularly in the case of LN cells, which had the widest capacity difference, contact with the second electrolyte was inhibited not only by the factor of porosity, but also the compressed Ni layer. Because of these two features, the initial capacity of 2LN-high showed the lowest value of $120 \mathrm{mAh} \mathrm{g}^{-1}$. When small $\mathrm{NaCl}$ was used for the $\mathrm{Na} / \mathrm{NiCl}_{2}$ cell, the difference in the initial capacity was the smallest. The 2SN-high granules did not exhibit this compressed $\mathrm{Ni}$ layer, and among all the $\mathrm{Na} / \mathrm{NiCl}_{2}$ cells, the cells made with small $\mathrm{NaCl}$ particles showed the most similar microstructure and initial capacity according to the difference in density.

The density clearly affected the cycling performance of the cells, as shown in Figure 3b,c. Although the low-density cells had a higher initial capacity than the high-density cells, the capacity began to decrease after 26 cycles for $2 \mathrm{MN}$-low and 2LN-low and after 40 cycles for $2 \mathrm{SN}$-low. The 2SN-low showed the lowest initial capacity of $165 \mathrm{mAh} \mathrm{g}^{-1}$ among the low-density cells, resulting in a thinner layer of $\mathrm{NiCl}_{2}$ on the $\mathrm{Ni}$ surface. The thinner $\mathrm{NiCl}_{2}$ layer tends to maintain the Ni connection more easily after discharge [18]. Therefore, although it started low, the initial capacity of $2 \mathrm{SN}-$ low was maintained for a relatively longer period than that of the other low-density cells. Notably, among the low-density cells, the capacity of $2 \mathrm{MN}$-low cell at the 80th cycle unexpectedly showed the highest value. However, because the two cells had almost the same maximum capacity (2MN-low: $186 \mathrm{mAh} \mathrm{g}^{-1} / 2 \mathrm{LN}-$ low: $185 \mathrm{mAh} \mathrm{g}^{-1}$ ) or 80th cycle capacity (as shown in Table 1), this difference was not very noticeable. Conversely, high-density cells showed the opposite tendency. First, the capacity of high-density cells was properly maintained to the 80th cycle. As shown in Figure 1b, the strong Ni connectivity provided high cycle retention. In $2 \mathrm{MN}$ high and 2LN-high, the capacity increased as the charge-discharge cycling proceeded; it seemed that the activation volume was gradually expanded. However, since the increased capacity at the 80th cycle was a low-level capacity of 143-144 $\mathrm{mAh} \mathrm{g}^{-1}$, the capacities of 2MN-high and 2LN-high cannot be an advantage. The most notable high-density cell was the 2SN-high cell. As shown in Figure 3c, the initial capacity of this cell was $8 \mathrm{mAh} \mathrm{g}^{-1}$, lower than that of $2 \mathrm{SN}-$ low; however, as cycling proceeded, its capacity increased to $165 \mathrm{mAh} \mathrm{g}^{-1}$ at the 80th cycle. At the 80th cycle, the capacity of 2SN-high was similar to those of 2MN-low and 2LN-low, and if the capacities of 2MN-low and 2LN-low had decreased with the same tendency after the 80th cycle, the capacity of 2SN-high would be higher than that of the two other corresponding cells. The coulombic efficiencies of all $\mathrm{Ni}$ cells were almost $100 \%$ except for the initial charge-discharge section. In summary, the high initial capacity and weak connectivity between Ni particles in the low-density cell were unfavorable to the cycling life. However, among high-density cells with strong $\mathrm{Ni}$ connectivity, 2MN-high and 2LN-high cells were not suitable due to their low capacity. Finally, because the $2 \mathrm{SN}$-high cell had a similar capacity to the low-density cells and exhibited a high cycle retention, small $\mathrm{NaCl}$ and high-density granules were selected as the optimal conditions for application in the $\mathrm{Na} /(\mathrm{Ni}, \mathrm{Fe}) \mathrm{Cl}_{2}$ cell. 


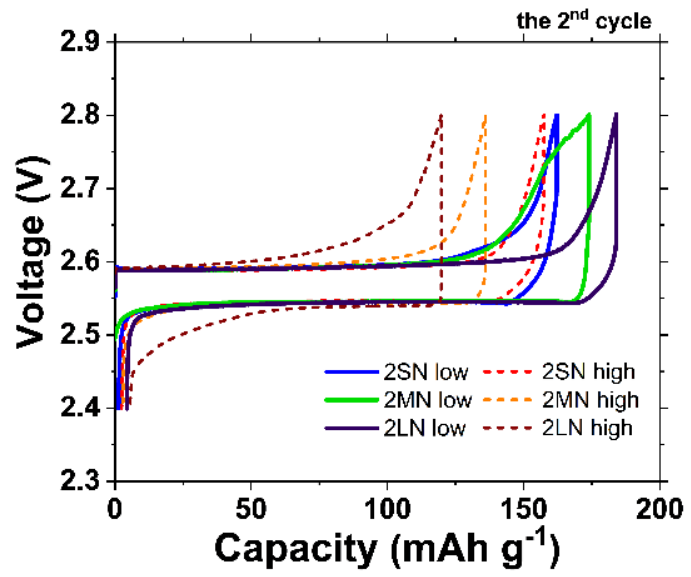

(a)

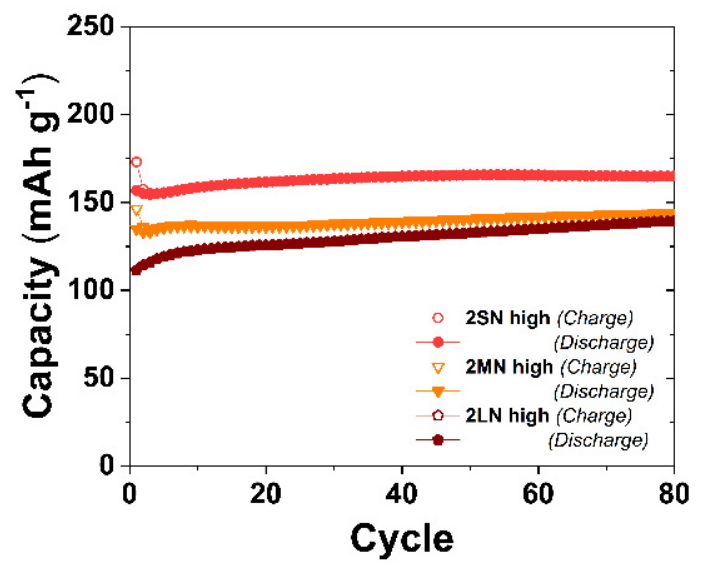

(c)

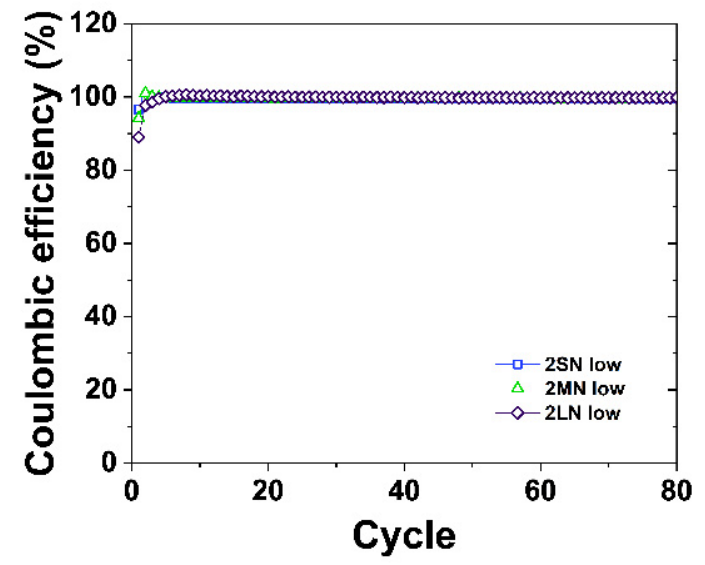

(e)

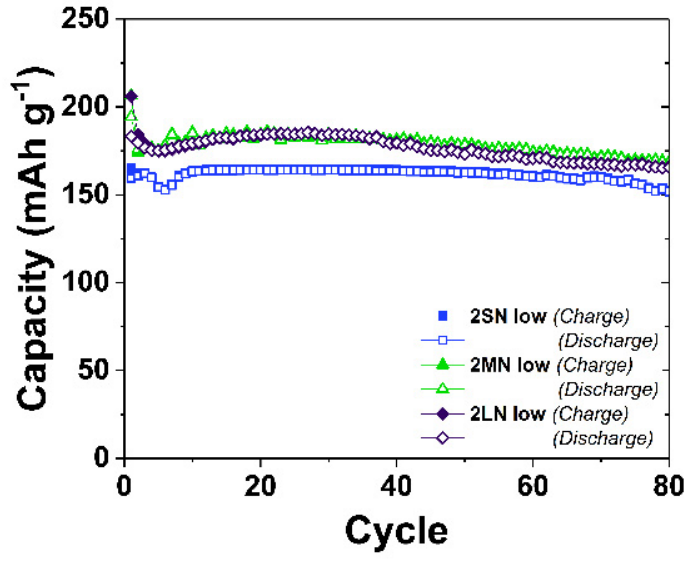

(b)

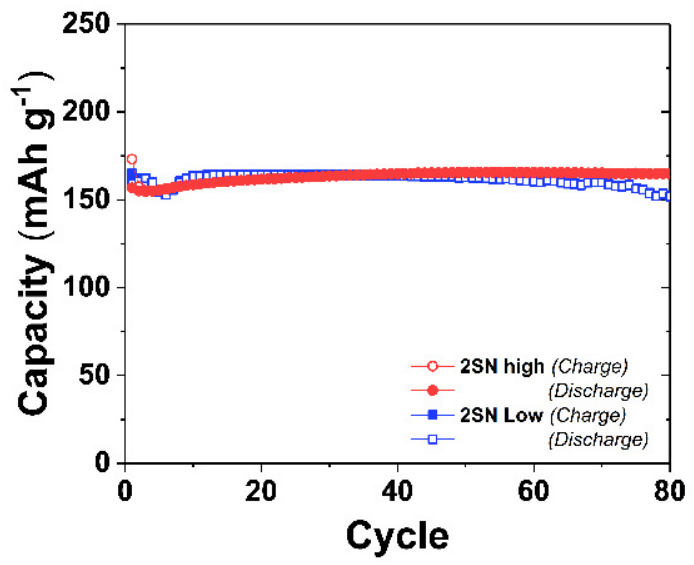

(d)

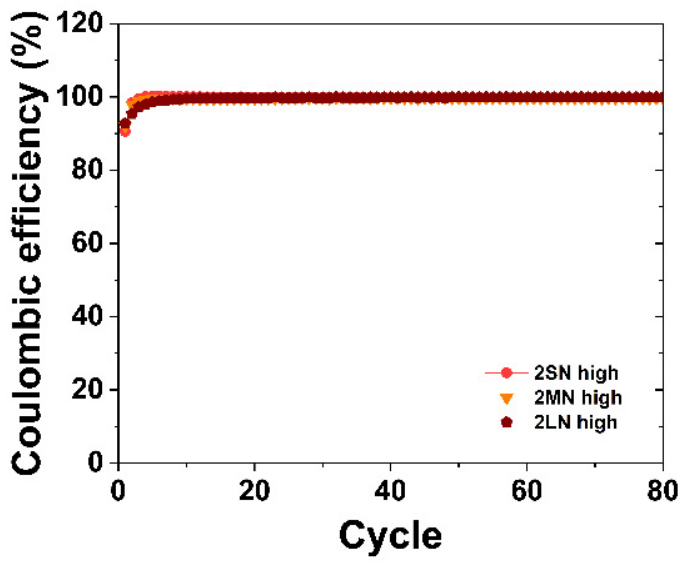

(f)

Figure 3. Electrochemical behavior of $\mathrm{Na} / \mathrm{NiCl}_{2}$ batteries. (a) Voltage profile of each cell at the second cycle; (b) cycling performance of low-density Ni cells to the 80th cycle; (c) cycling performance of high-density Ni cells to the 80th cycle; (d) comparison of cycling performance between 2SN-high and 2SN-low cells; (e,f) Coulombic efficiency. 
Table 1. Variation in the charge capacity with different $\mathrm{NaCl}$ sizes and active metal ratios.

\begin{tabular}{|c|c|c|c|c|c|c|c|c|}
\hline \multirow{3}{*}{ Cell Type } & \multirow{3}{*}{ Cell Name } & \multirow{3}{*}{$\begin{array}{l}\text { NaCl Size } \\
\quad(\mu \mathrm{m})\end{array}$} & \multirow{3}{*}{$\begin{array}{c}\text { Granule } \\
\text { Density (\%) }\end{array}$} & \multicolumn{3}{|c|}{ Ratio of Composition } & \multirow{2}{*}{\multicolumn{2}{|c|}{$\begin{array}{c}\text { Charge Capacity } \\
\left(\mathrm{mAh} \mathrm{g}^{-1}\right)\end{array}$}} \\
\hline & & & & \multirow{2}{*}{$\begin{array}{c}\mathrm{Ni} \\
\text { (wt.\%) }\end{array}$} & \multirow{2}{*}{$\begin{array}{c}\text { Fe } \\
(w t . \%)\end{array}$} & \multirow{2}{*}{$\begin{array}{l}\mathrm{NaCl} \\
\text { (wt.\%) }\end{array}$} & & \\
\hline & & & & & & & 2nd & 80th \\
\hline \multirow{6}{*}{$\mathrm{Na} / \mathrm{NiCl}_{2}$} & 2SN-low & $<38$ & 28 & \multirow{2}{*}{66.7} & \multirow{6}{*}{-} & \multirow{2}{*}{33.3} & 165 & 152 \\
\hline & 2SN-high & (Small) & 52 & & & & 157 & 165 \\
\hline & 2MN-low & $38-150$ & 32 & \multirow{2}{*}{66.7} & & \multirow{2}{*}{33.3} & 174 & 169 \\
\hline & 2MN-high & (Medium) & 52 & & & & 136 & 143 \\
\hline & 2LN-low & $150-300$ & 37 & \multirow{2}{*}{66.7} & & \multirow{2}{*}{33.3} & 184 & 166 \\
\hline & 2LN-high & (Large) & 55 & & & & 120 & 140 \\
\hline \multirow{2}{*}{$\mathrm{Na} /(\mathrm{Ni}, \mathrm{Fe}) \mathrm{Cl}_{2}$} & 1.5LNF-low & $150-300$ & - & \multirow{2}{*}{30.1} & \multirow{2}{*}{30.1} & \multirow{2}{*}{39.8} & 263 & 172 \\
\hline & 1.5SNF-high & $<38$ & 56 & & & & 247 & 224 \\
\hline
\end{tabular}

\subsection{Application of Small $\mathrm{NaCl}$ on the $\mathrm{Na} / \mathrm{NiCl}_{2}$ and $\mathrm{Na} /(\mathrm{Ni}, \mathrm{Fe}) \mathrm{Cl}_{2}$ Cell of Metal/ $\mathrm{NaCl}=1.5 / 1$}

In our previous Ni-Fe composite cells, such as 1.5LNF-low, the cathode granules had been made by milling the cathode powder without pressure. Therefore, the density of 1.5LNF-low granules was lower than that of low-density Ni cells in this study. For comparison with 1.5LNF-low cells, small $\mathrm{NaCl}$ and high-density granules, which had been the optimal conditions in the Ni-only cell test, were applied to the new Ni-Fe composite cell. The backscattering image of Figure $4 \mathrm{a}$, b shows the connection difference of the two Ni-Fe composite cells. Through the shape of particle cross-sections, the difference in connectivity between the two cells was confirmed more clearly. As seen in Figure $4 \mathrm{c}, \mathrm{d}$, both Ni-Fe cells contained well-connected Ni-Fe composites. The difference in the microstructure according to the density is similar to that of the Ni-only cells. Many contact points appeared between the active metal particles in the 1.5LNF-low granules (inset of Figure 4c). Conversely, in the 1.5SNF-high microstructure shown in Figure $4 \mathrm{~d}$, the active metal particles were strongly connected, as in the high-density Ni cells. In addition, the microstructure of 1.5SNF-high was much denser than that of 1.5LNF-low due to the high pressure.

As shown in the voltage profile of Figure 5a, in both Ni-Fe composite cells, the roles of $\mathrm{Ni}$ and $\mathrm{Fe}$ were properly divided according to the ratio of $\mathrm{Ni} / \mathrm{Fe}=1 / 1$. Specifically, most of the capacity was acquired through the Fe reaction, and approximately $10 \%$ of the $\mathrm{Ni}$ reacted. This small amount of $\mathrm{Ni}$ reaction forms a thin $\mathrm{NiCl}_{2}$ layer, which has an advantage in that it conserves the Ni connection as a conduction path. The capacity of both cells was increased by changing the metal $/ \mathrm{NaCl}$ ratio to $1.5 / 1$. The theoretical capacities of 1.5SNF-high and 1.5LNF-low are $314 \mathrm{mAh} \mathrm{g}^{-1}$; that is, higher than the theoretical capacities of Ni-only cells ( $306 \mathrm{mAh} \mathrm{g}^{-1}$ on the ratio of metal $\left./ \mathrm{NaCl}=1.5 / 1\right)$ due to Fe particles being lighter than Ni particles. The initial capacities, which also followed the tendency of Ni-only cells, were 263 and $247 \mathrm{mAh} \mathrm{g}^{-1}$ for 1.5LNF-low and 1.5SNF-high, respectively. In both cells, the Fe reaction was decreased at the 80th cycle. In particular, the Fe reaction of 1.5LNF-low declined significantly. On the other hand, the Ni reaction was largely constant between the second cycle and the 80th cycle. Prior to the cycle retention test, the stepwise rate capability test of the 1.5SNF-low cell was conducted at five different current densities over 25 cycles in order to confirm the high-speed charge-discharge capability (as shown in Figure 5b). The starting current density was $34 \mathrm{~mA} \mathrm{~g}^{-1}$, which was doubled $\left(67 \mathrm{~mA} \mathrm{~g}^{-1}\right)$ and quadrupled $\left(134 \mathrm{~mA} \mathrm{~g}^{-1}\right)$ in the second and third steps, respectively. In the first to third steps, the charge-discharge capacity was higher than $200 \mathrm{mAh} \mathrm{g}^{-1}$ without a considerable capacity loss.

When the rate was returned to the initial current density in step four, the charge capacity did not fully return to the initial capacity. However, in the last step of $67 \mathrm{~mA} \mathrm{~g}^{-1}$, the charge capacity returned to the same capacity as that in the second step. Figure $5 c$ 
shows the voltage profile for each step. As the C-rate increased, the charge-discharge voltage in the Fe plateau was increased. However, the portion of Ni reaction was constant at the various C-rates, and only the Fe reaction showed a tendency to decrease. In the SNF-high at the 80th cycle, the Fe reaction decreased and the Ni reaction was slightly increased; as a result, the capacity remained near the initial capacity.

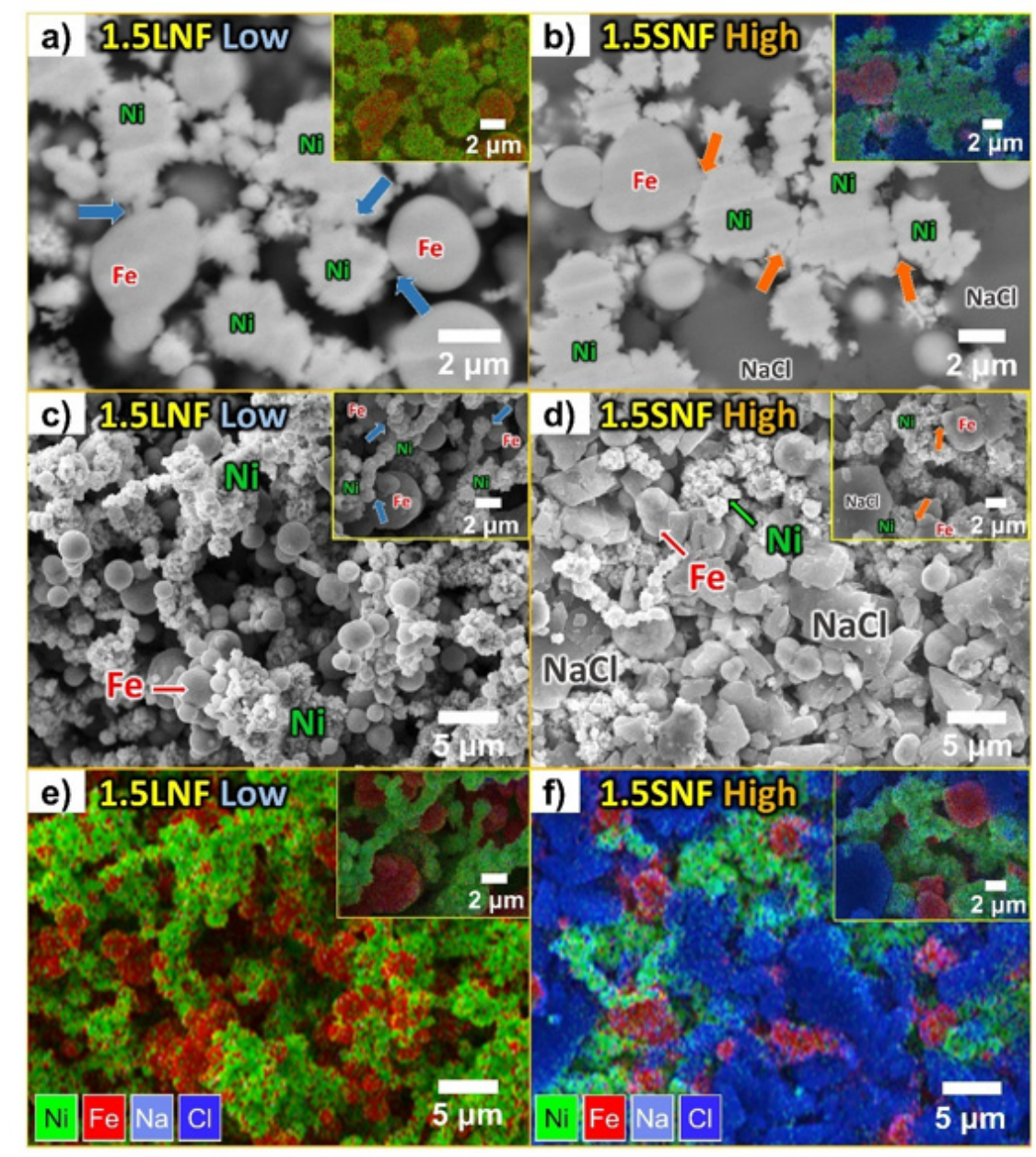

Figure 4. SEM images of cathode granules. (a) backscattering image for contacting $\mathrm{Ni}$ and $\mathrm{Fe}$ particles in 1.5LNF-low granules; (b) backscattering image for well-connected $\mathrm{Ni}$ and Fe particles in 1.5SNF-high granule; (c,e) microstructure of the 1.5LNF-low cell and Ni-Fe connections similar to those of the 2LN-low cell; $(\mathbf{d}, \mathbf{f})$ microstructure of the 1.5SNF-high cell and strong connections among $\mathrm{Ni}$ and Fe particles.

The cycling properties in 1.5SNF-high were tested at a higher C-rate (of $0.30 \mathrm{C}$ ) than 1.5LNF-low $(0.13 \mathrm{C})$ to rapidly determine its cycling life properties. Nevertheless, $1.5 \mathrm{SNF}-$ high showed outstanding performance and higher stability during high-speed chargedischarge. Compared with Ni-only cells with the same metal/ $\mathrm{NaCl}$ ratio, $1.5 \mathrm{LNF}-\mathrm{low}$ also showed significantly better cycle retention owing to the $\mathrm{Ni}-\mathrm{Fe}$ composite microstructure [18]. However, the microstructure of the 1.5LNF-low cell had many simple contacts between metal particles-thus, the electronic conduction path was disconnected by the formation of a chloride layer, and the capacity consistently decreased from the initial capacity. As shown in Figure 5d, the capacity of 1.5LNF-low decreased from $263 \mathrm{mAh} \mathrm{g}^{-1}$ at the second cycle to $172 \mathrm{mAh} \mathrm{g}^{-1}$ at the 80 th cycle, thus $1.5 \mathrm{LNF}-$ low retained $65 \%$ of initial capacity to the 80th cycle. On the other hand, 1.5SNF-high continued to stabilize until the 46th cycle after the rate test, and its capacity slightly increased relative to that at the end of the rate test. Similar to the results of the Ni cells, the internal spaces in 1.5SNF-high that 
allowed the second electrolyte to penetrate were narrower than those of 1.5LNF-low owing to the small $\mathrm{NaCl}$ and high pressure. Because of these narrow internal spaces, 1.5SNF-high had a lower initial capacity than 1.5LNF-low. However, as discussed earlier in terms of the microstructure, 1.5SNF-high showed high cycle retention due to the strong connection between metal particles. The initial capacity of $1.5 \mathrm{SNF}-\mathrm{high}$ was $247 \mathrm{mAh} \mathrm{g}^{-1}$ at $0.13 \mathrm{C}$, and the capacity at the 80 th cycle was $224 \mathrm{mAh} \mathrm{g}^{-1}$ at $0.30 \mathrm{C}$, although the current density increased to twice that of 1.5LNF-low. Furthermore, 1.5SNF-high maintained its capacity from the 80 th cycle to the 100 th cycle, thereby retaining $91 \%$ of its initial capacity after the 100th cycle. As seen in Figure 5e, the coulombic efficiency of 1.5SNF-high also remained stable at approximately $100 \%$, except for the cycle in which the current density was changed during the rate test. Figure $5 \mathrm{f}$ shows the XRD spectra of raw powder and cathode materials in the 1.5SNF-high. After charging, the $\mathrm{FeCl}_{2}$ peak showed high intensity compared to the $\mathrm{NiCl}_{2}$ peak. Therefore, it can be explained that the cathode granule was manufactured as intended. In summary, in the case of the 1.5SNF-high cell, which contained an optimized microstructure, the initial capacity was $16 \mathrm{mAh} \mathrm{g}^{-1}$, lower than the previous condition of 1.5LNF-low. However, 1.5SNF-high showed a high capacity of $224 \mathrm{mAh} \mathrm{g}^{-1}$ to the 100 th cycle and a high coulombic efficiency of $100 \%$. Eventually, the retained capacity of 1.5SNF-high increased approximately $30 \%$ compared to $1.5 \mathrm{LNF}-\mathrm{low}$.

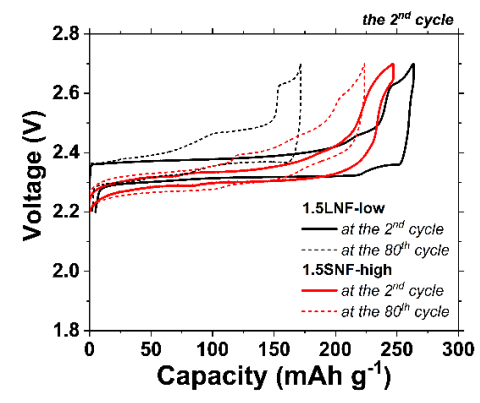

(a)

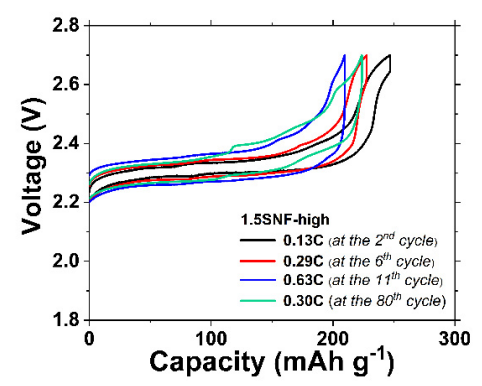

(c)

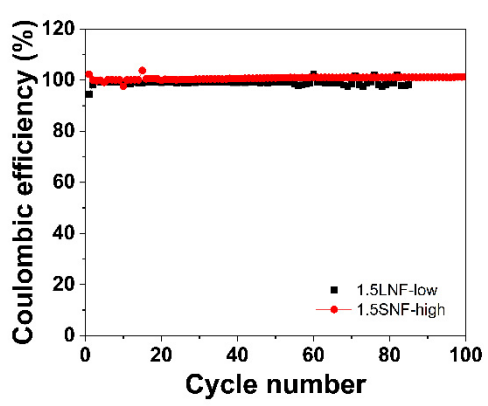

(e)

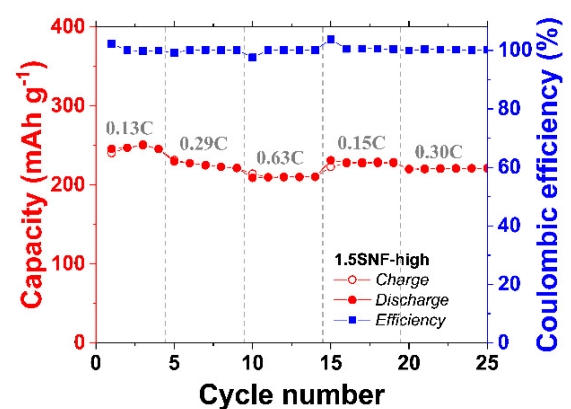

(b)

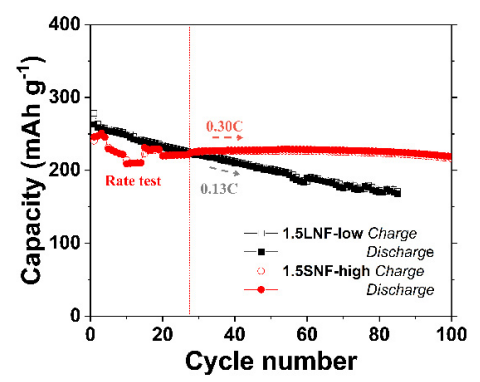

(d)

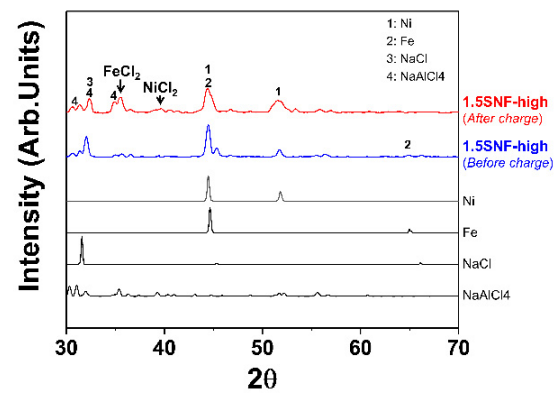

(f)

Figure 5. Electrochemical properties of 1.5LNF-low and 1.5SNF-high. (a) voltage profile; (b) rate capability of 1.5SNF-high cell; (c) voltage profile according to C-rate; (d) cycle performance for 100 cycles; (e) Coulombic efficiency; (f) X-ray diffraction (XRD) spectra. 


\section{Conclusions}

We investigated the effect of the cathode microstructure on the electrochemical properties of cells for a sodium metal chloride battery. The microstructure was designed to improve the cycle retention of a high-capacity $\mathrm{Na} /(\mathrm{Ni}, \mathrm{Fe}) \mathrm{Cl}_{2}$ battery. The microstructure was designed by controlling the $\mathrm{NaCl}$ size and the granule density. In high-density granules, strong connections between metal particles were created owing to the high pressure, which was a key factor in the high cycle retention. However, high-density granules using large $\mathrm{NaCl}$ had a low porosity and a compressed $\mathrm{Ni}$ layer that obstructed the contact between the second electrolyte and cathode materials, which caused an insufficient initial capacity. On the other hand, using small $\mathrm{NaCl}$ mitigated the problems caused by the high pressure conditions, such as a compressed $\mathrm{Ni}$ layer on the $\mathrm{NaCl}$ surface, and the microstructure also had strong connections between Ni particles. Eventually, a $\mathrm{Na} / \mathrm{NiCl}_{2}$ cell with high cycle retention was fabricated with small $\mathrm{NaCl}$ and high-density granules while minimizing the initial capacity loss. Finally, we applied the optimized conditions to fabricate cathode granules of a $\mathrm{Na} /(\mathrm{Ni}, \mathrm{Fe}) \mathrm{Cl}_{2}$ cell, which preserved the advantages of this cathode, such as its high capacity and low cost. This cell successfully maintained a capacity of $224 \mathrm{mAh} \mathrm{g}^{-1}$ at the 100th cycle. These findings show that the cathode microstructure must be controlled for high cycle retention in a sodium metal chloride battery, and creating strong Ni connections is the most important point.

Author Contributions: Conceptualization, B.-M.A., C.-W.A. and J.-H.C.; formal analysis, B.-M.A. and C.-W.A.; investigation, B.-D.H. and J.-J.C.; methodology, Y.-D.K.; writing-original draft preparation, B.-M.A.; writing-review and editing, C.-W.A. and J.-H.C.; supervision, J.-H.C.; project administration, S.-K.L.; funding acquisition, S.-K.L. All authors have read and agreed to the published version of the manuscript.

Funding: This research was supported by a Planning (KETEP) grant funded by the Korea government (MOTIE) (20172420108430, Development of high-capacity technology of high-safety sodiumferronickel chloride battery).

Institutional Review Board Statement: Not applicable.

Informed Consent Statement: Not applicable.

Data Availability Statement: The data presented in this study are available from the corresponding authors upon reasonable request.

Conflicts of Interest: The authors declare no conflict of interest.

\section{References}

1. Killer, M.; Farrokhseresht, M.; Paterakis, N.G. Implementation of large-scale Li-ion battery energy storage systems within the EMEA region. Appl. Energy 2020, 260, 114166. [CrossRef]

2. Zhu, Q.-N.; Wang, Z.-Y.; Wang, J.-W.; Liu, X.-Y.; Yang, D.Y.; Cheng, L.-W.; Tang, M.-Y.; Qin, Y.; Wang, H. Challenges and strategies for ultrafast aqueous zinc-ion batteries. Rare Met. 2021, 40, 309-328. [CrossRef]

3. Lei, K.-X.; Wang, J.; Chen, C.; Li, S.-Y.; Wang, S.-W.; Zheng, S.-J.; Li, F.-J. Recent progresses on alloy-based anodes for potassium-ion batteries. Rare Met. 2020, 39, 989-1004. [CrossRef]

4. Skyllas-kazacos, M.; Grossmith, F. Efficient vanadium redox flow cell. J. Electrochem. Soc. 1987, 134, 2950-2953. [CrossRef]

5. Stefano, S.; Ratnakumar, B.V.; Bankston, C.P. Advanced rechargeable sodium batteries with novel cathodes. J. Power Sources 1990, 29, 301-309. [CrossRef]

6. Zhan, X.; Bonnett, J.F.; Engelhard, M.H.; Reed, D.M.; Sprenkle, V.L.; Li, G. A High-Performance Na-Al Battery Based on Reversible $\mathrm{NaAlCl}_{4}$ Catholyte. Adv. Energy Mater. 2020, 10, 2001378. [CrossRef]

7. Zhan, X.; Bowden, M.E.; Lu, X.; Bonnett, J.F.; Lemmon, T.; Reed, D.M.; Sprenkle, V.L.; Li, G. A Low-Cost Durable Na-FeCl2 Battery with Ultrahigh Rate Capability. Adv. Energy Mater. 2020, 10, 1903472. [CrossRef]

8. Li, G.; Lu, X.; Kim, J.Y.; Viswanathan, V.V.; Meinhardt, K.D.; Engelhard, M.H.; Sprenkle, V.L. An Advanced Na-FeCl2 ZEBRA Battery for Stationary Energy Storage Application. Adv. Energy Mater. 2015, 5, 1500357. [CrossRef]

9. Keith, T.A.; Thackeray, M.M. The crystal Chemistry of the Na_FeCl2 Battery. J. Electrochem. Soc. 1988, 135, $2121-2123$.

10. Moseley, P.T.; Bones, R.J.; Teagle, D.A.; Bellamy, B.A.; Hawes, W.M. Stability of beta alumina electrolyte in sodium/FeCl 2 (Zebra) cells. J. Electrochem. Soc. 1989, 136, 1361-1368. [CrossRef] 
11. Lu, X.; Li, G.; Kim, J.Y.; Lemmon, J.P.; Sprenkle, V.L.; Yang, Z. The effects of temperature on the electrochemical performance of sodium-nickel chloride batteries. J. Power Sources 2012, 215, 288-295. [CrossRef]

12. Li, G.; Lu, X.; Kim, J.Y.; Lemmon, J.P.; Sprenkle, V.L. Cell degradation of a Na-NiCl2 (ZEBRA) battery. J. Mater. Chem. A 2013, 1, 14935-14942. [CrossRef]

13. Kim, J.; Jo, S.H.; Bhavaraju, S.; Eccleston, A.; Kang, S.O. Low temperature performance of sodium-nickel chloride batteries with NaSICON solid electrolyte. J. Electroanal. Chem. 2015, 759, 201-206. [CrossRef]

14. Li, G.; Lu, X.; Kim, J.Y.; Meinhardt, K.D.; Chang, H.J.; Canfield, N.L.; Sprenkle, V.L. Advanced intermediate temperature sodium-nickel chloride batteries with ultra-high energy density. Nat. Commun. 2016, 7, 10683. [CrossRef] [PubMed]

15. Li, Y.; Wu, X.; Wang, J.; Gao, X.; Hu, Y.; Wen, Z. Ni-less cathode with 3D free-standing conductive network for planar Na-NiCl2 batteries. Chem. Eng. J. 2020, 387, 124059. [CrossRef]

16. Gao, X.; Hu, Y.; Li, Y.; Wang, J.; Wu, X.; Yang, J.; Wen, Z. High-Rate and Long-Life Intermediate-Temperature Na-NiCl2 Battery with Dual-Functional Ni-Carbon Composite Nanofiber Network. ACS Appl. Mater. Interfaces 2020, 12, 24767-24776. [CrossRef]

17. Ahn, C.-W.; Kim, M.; Hahn, B.-D.; Hong, I.; Kim, W.; Moon, G.; Lee, H.; Jung, K.; Park, Y.-C.; Choi, J.-H. Microstructure design of metal composite for active material in sodium nickel-iron chloride battery. J. Power Sources 2016, 329, 50-56. [CrossRef]

18. Ahn, B.-M.; Ahn, C.-W.; Hahn, B.-D.; Choi, J.-J.; Kim, Y.-D.; Lim, S.-K.; Jung, K.; Park, Y.-C.; Choi, J.-H. Easy approach to realize low cost and high cell capacity in sodium nickel-iron chloride battery. Compos. Part B Eng. 2019, 168, 442-447. [CrossRef]

19. Kim, J.; Jo, S.H.; Kim, J.-S.; Bhavaraju, S.; Kang, S.O. Investigation of manufacturing parameters for NaCl-Ni granule type cathodes used in low temperature NaSICON sodium-metal chloride batteries. J. Alloy. Compd. 2016, 665, 288-293. [CrossRef]

20. Kim, S.-M.; Lee, S.-M.; Jung, K.; Park, Y.-C.; Cho, N.-U.; Choi, J.-H.; Kim, H.-S. Influence of Carbon Coating on Beta-Alumina Membrane for Sodium-Nickel Chloride Battery. Bull. Korean Chem. Soc. 2015, 36, 2869-2874. [CrossRef]

21. Matsumae, Y.; Obata, K.; Ando, A.; Yanagi, M.; Kamei, Y.; Ueno, K.; Dokko, K.; Watanabe, M. Effects of Sulfur Loading, Cathode Porosity, and Electrolyte Amount on Li-S Battery Performance with Solvate Ionic Liquid Electrolyte. Electrochemistry 2019, 87, 254-259. [CrossRef] 